\title{
Apoptosis induction on human breast cancer T47D cell line by
}

\section{extracts of Ancorina sp. [version 1; peer review: 2 approved}

\section{with reservations]}

\author{
Woro Anindito Sri Tunjung (D), Puspa Restu Sayekti
}

Faculty of Biology, Universitas Gadjah Mada, Yogyakarta, 55281, Indonesia

V1 First published: 07 Feb 2019, 8:168

https://doi.org/10.12688/f1000research.17584.1

Latest published: $10 \mathrm{Apr} 2019, \mathbf{8 : 1 6 8}$

https://doi.org/10.12688/f1000research.17584.2

\section{Abstract}

Background: Breast cancer is the second leading cause of death in women. Alternative medicine with high efficacy is needed for breast cancer treatments, for example induction of apoptosis using natural products. It has been found that many natural apoptosis-inducing compounds are isolated from marine sponge. The objective of this study is to analyze the ability of extracts of the sponge Ancorina sp. to induce apoptosis on human breast cancer T47D cell line and find out its mechanism.

Methods: T47D cells were treated with crude extracts of methanol, dichloromethane:methanol (1:1) and dichloromethane Ancorina sp. for $24 \mathrm{~h}$, and doxorubicin was used as a positive control. Methods used for this study were MTT assay to examine cell viability and determine IC $_{50}$ of the three extracts, while the percentage of apoptosis and caspase- 3 were investigated by flow cytometry.

Results: $\mathrm{IC}_{50}$ values of methanol, dichloromethane:methanol (1:1), and dichloromethane extract were $84.25,121.45$, and $99.85 \mu \mathrm{g} / \mathrm{mL}$ respectively. The percentages of apoptotic cells after treatment with methanol, dichloromethane:methanol (1:1), and dichloromethane extracts were $88.68,27.54$ and $53.63 \%$ respectively, whereas the percentage of caspase- 3 was $77.87,12.66$ and $12.97 \%$, respectively. Conclusions: These results revealed that all extracts of Ancorina sp. have strong or moderate cytotoxicity and have the ability to induce apoptosis on T47D human breast cancer cell line. However, methanol crude extract has high efficacy to induce apoptosis through caspase-3 activation compared to the other extracts. Hence methanol extract warrants further investigation as a natural medicine for human breast cancer.

Keywords

Ancorina sp., cytotoxicity, apoptosis, caspase-3, breast cancer

\section{Open Peer Review \\ Approval Status \\ 1 \\ 2 \\ version 2 \\ (revision) \\ 10 Apr 2019 \\ version 1 \\ 07 Feb 2019

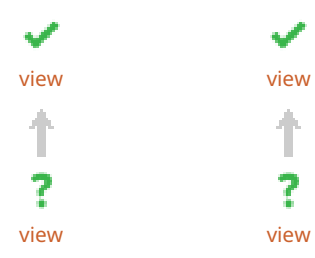 \\ 1. Sutiman Bambang Sumitro (D), Brawijaya \\ University, Malang, Indonesia \\ 2. Richard Luke Daniels (D), The College of \\ Idaho, Caldwell, USA \\ Any reports and responses or comments on the article can be found at the end of the article.}


Corresponding author: Woro Anindito Sri Tunjung (wanindito@ugm.ac.id)

Author roles: Tunjung WAS: Conceptualization, Data Curation, Formal Analysis, Funding Acquisition, Investigation, Methodology, Project Administration, Resources, Supervision, Validation, Visualization, Writing - Original Draft Preparation, Writing - Review \& Editing; Sayekti PR: Data Curation, Formal Analysis, Investigation, Methodology, Resources, Validation, Visualization, Writing - Original Draft Preparation

Competing interests: No competing interests were disclosed.

Grant information: This work was financially supported by Penelitian Dasar UnggulanPerguruan Tinggi No: 24/UN1/DITLIT/DITLIT/LT/2018 from Indonesia Ministry of Research, Technology and Higher education (to W.A.S.T).

The funders had no role in study design, data collection and analysis, decision to publish, or preparation of the manuscript.

Copyright: ( 2019 Tunjung WAS and Sayekti PR. This is an open access article distributed under the terms of the Creative Commons Attribution License, which permits unrestricted use, distribution, and reproduction in any medium, provided the original work is properly cited.

How to cite this article: Tunjung WAS and Sayekti PR. Apoptosis induction on human breast cancer T47D cell line by extracts of Ancorina sp. [version 1; peer review: 2 approved with reservations] F1000Research 2019, 8:168 https://doi.org/10.12688/f1000research.17584.1

First published: 07 Feb 2019, 8:168 https://doi.org/10.12688/f1000research.17584.1 


\section{Introduction}

Breast cancer is the second leading cause of death in women after cervical cancer. In 2016 breast cancer cases have occurred in 40 per 100,000 women in Indonesia ${ }^{1}$. Medical treatment for breast cancer is currently widely applied ${ }^{2}$. However, medical treatment can cause side effects, namely the death of healthy cells surrounding cancer cells ${ }^{3}$. Alternative methods of breast cancer treatment with reduced side effects are needed, such as treatments using natural anticancer agents ${ }^{3}$.

There are many cancer treatment methods such as antiangiogenesis therapy ${ }^{4}$, cell cycle inhibitors ${ }^{5}$, and photodynamic therapy ${ }^{6}$. Induction of apoptosis is the most common approach in cancer therapy because apoptosis has specific abilities to kill certain cells ${ }^{7}$. One characteristic of cancer cell is loss of ability for apoptosis ${ }^{8}$. The ability of apoptosis to kill abnormal cells can prevent the occurrence of cancer growth ${ }^{9}$. Induction of apoptosis occurs through three apoptotic-signaling pathways:extrinsic, intrinsic and perforin/granzyme pathways. Apoptosis path activation is marked by the activation of caspases. Caspase is found in normal cells as an inactive zymogen (procaspase). Active caspase activates other caspases, forming the 'caspase cascade'. Activation of caspase 8 and 9 will cause activation of caspase- 3 as a downstream effector, which induces apoptosis ${ }^{10}$.

Previous studies found many natural apoptosis-inducing compounds isolated from marine sponge that can be developed as natural medicine ${ }^{11}$. Fraction of Negombata magnifica sponge is able to induce apoptosis in hepatocellular carcinoma ${ }^{12}$. Sponge extract of Haliclona sp. able to increase the percentage of apoptosis and significantly increase the expression of apoptotic gene p53, p21, caspase-8, and caspase-3 in A549 lung cancer cells ${ }^{13}$.

Natural anticancer agents are usually extracted by a particular solvent. Different solvents cause different effects on the disease. Some previous researchers have isolated sponge bioactive compounds using both polar and non-polar solvents. For example, cytotoxic compounds have been successfully isolated from sponge Dactylospongia elegans and Pachychalina alcaloidifera using methanol ${ }^{14,15}$. Organic compounds have been successfully isolated from the sponge Condrosia reniformes, Tethya rubra, Tethya ignis, Mycale angulosa and Dysidea avara as a drug therapy for Chagas disease using acetone solvents ${ }^{16}$. Terpenoids have been successfully isolated from sponge Iricina sp. and Spongia sp. using ethanol solvent ${ }^{17}$. Anticancer compounds have been successfully isolated from Petrosia sp., Jaspis sp. and heterogeneous Pericharax using dichloromethane:methanol $(1: 1)^{18}$. Some studies also mention that sponge bioactive compounds, antiviral, antimicrobial, antifungal, and anticancer compounds, have been successfully isolated with methanol ${ }^{19-21}$, ethanol ${ }^{22}$, dichloromethane and combination of dichloromethane:methanol $(1: 1)^{23-26}$.

The objective of this study is to determine the cytotoxicity of Ancorina sp. extract in breast cancer T47D cells and measure extract-induced apoptosis through activation of caspase-3. In this study we use three solvents: methanol (polar), dichloromethane (non-polar) and mixture of both solvents to determine the most effective solvent. Furthermore this study used T47D cells as a model for breast cancer cells because T47D cells are able to express caspase-3, which is an effector of apoptotic induction ${ }^{27}$.

\section{Methods}

Sample preparation and determination

Ancorina sp. were collected from Wedi Ombo Beach, Gunungkidul, Yogyakarta, Indonesia. Samples were washed to remove debris and residual salt. Samples were transferred to the laboratory in methanol, dichloromethane and dichloromethane:methanol (1:1) under cool condition.

\section{Extraction}

Fresh samples were crushed in a blender in methanol, dichloromethane and dichloromethane methanol (1:1) then macerated for 24 hours. The samples were filtered and the residue was re-extracted for two times. The total filtrate was then evaporated to obtain crude extract paste.

\section{Cell line culture}

We used T47D cells obtained from Integrated Laboratory of Research and Testing, Universitas Gadjah Mada (LPPT UGM).

The cells were cultured in RPMI 1640 medium supplemented with $10 \%$ FBS, $2 \%$ penicillin streptomycin and $0.5 \%$ Fungizone. Cells were harvested after reaching $80 \%$ confluence using $0.25 \%$ Trypsin-EDTA. Cells were cultured in 96-well microplates $\left(1 \times 10^{3}\right.$ cells/well) in $100 \mu \mathrm{L} \mathrm{RPMI}$ and incubated at $37^{\circ} \mathrm{C}$ with $5 \%$ $\mathrm{CO}_{2}$ overnight.

Doxorubicin at $5 \mu \mathrm{g} / \mathrm{mL}$ was used as the positive control whereas T47D cells cultured in medium was used as the negative control and cells cultured in $0.5 \%$ DMSO in medium was used as the solvent blank.

\section{Cytotoxicity assay}

Cytotoxicity was assessed using the MTT assay. After the cells were incubated for $24 \mathrm{~h}$ with the serial dilution from 15.68 to $250 \mu \mathrm{g} / \mathrm{mL}, 0.5 \%$ MTT solution was added and the cells were incubated for $4 \mathrm{~h}$ followed by addition of stopper reagent ( $10 \%$ SDS in $0.1 \mathrm{~N} \mathrm{HCl}$ ). The optical density (OD) was measured at $550 \mathrm{~nm}$ using Microplate Reader BIO-RAD 680XR. MTT data was then analyzed by Probit to determine the $\mathrm{IC}_{50}$ value. $\mathrm{IC}_{50}$ of each extract is used for FACS experiment.

\section{Apoptosis and caspase- 3 assay}

Briefly, T47D cells were seeded in 6-well microplates in $3 \times 10^{3} \mu \mathrm{L}$ RPMI. In total, $1 \times 10^{6}$ cells were treated by $\mathrm{IC}_{50}$ concentrations of three extracts or doxorubicin for $24 \mathrm{~h}$. Cells were stained by Annexin V-PI Biolegend for apoptosis test and by BD Cytofix / Cytoperm $^{\mathrm{TM}}$ for caspase-3 activation test. The sample was measured using flow cytometer BD FACSCalibur ${ }^{\mathrm{TM}}$. Flowcytometry output by BD FACSCalibur ${ }^{\mathrm{TM}}$ was shown in four quadrants. The first quadrant contains normal living cells population that respond negatively to Annexin V-FITC and propidium iodide (PI). Second quadrant contains early apoptotic cells populations that 
respond positively to Annexin V-FITC. Third quadrant contains the late apoptotic cells population which responds positively to Annexin V-FITC and Propidium Iodide (PI). Whereas in the fourth quadrant contains a population of necrotic cells that respond negatively to Annexin V-FITC and respond positively to $\mathrm{PI}^{28}$.

Data analysis

The $\mathrm{IC}_{50}$ value was determined by Probit analysis. IC50 value and percentage of apoptosis are further analyzed by one-way ANOVA and Tukey's test at 5\% significance level using IBM SPSS Statistic 23.0 program. $\mathrm{P}<0.05$ indicated statistical significance.

\section{Results}

\section{Cytotoxicity}

The cell viability of T47D cells after methanol, dichloromethane and dichloromethane: methanol (1:1) extracts treatment are presented in Figure 1. The concentration of extracts reduced the viability of investigated cells by $50 \%\left(\mathrm{IC}_{50}\right)$, which has been reported in Table 1.

All Ancorina sp. extracts inhibited the proliferation of cancer cells in a dose dependent manner. The higher concentration of extract caused the lower percentage of T47D cell viability. All extracts were cytotoxic to T47D cells. $\mathrm{IC}_{50}$ value of methanol was significantly different to dichloromethane:methanol but wasn't significantly different to dichloromethane.

\section{Apoptosis and caspase- 3 activation assay}

We analyzed cell death qualitatively by examining cell morphological change and quantitively by flow cytometry using Annexin-V after $24 \mathrm{~h}$ incubation of extracts.

Cell morphology after treatment can be seen in Figure 2. Morphology of T47D cell showed that methanol extract caused most cells population to undergo death (approximately more than $70 \%$ ), while dichloromethane extract resulted in almost half cell population deaths. The combination of methanol and dichloromethane (1:1) extract causes fewer cell deaths $(<50 \%)$.

The control (DMSO) cell did not cause cell death but after doxorubicin and extract treatment most cells undergo death. This data supports the cytotoxicity assay that the Ancorina sp. extracts successfully induced cell death.

Detection of apoptosis marker after treatment by extracts can be seen in Figure 3.

All Ancorina sp. extracts increase the percentage of apoptotic cells compared to control cells (Figure 3). The highest percentage of apoptosis was obtained in the methanol group (88.68\%), which was even higher than doxorubicin as a positive control $(75.74 \%)$ (Table 2).

The three extracts showed the same pattern with doxorubicin, i.e. a high percentage of apoptotic cell while the percentage of necrotic cells is low (Table 2).

We further investigated the apoptotic mechanism by examining the percentage of caspase-3. Detection of caspase- 3 can be seen in Figure 4, while percentage of caspase- 3 activation and correlation between percentage of apoptosis and caspase- 3 activation can be seen in Table 3 and Figure 5, respectively.

The highest percentage of caspase- 3 was detected with methanol extract, which almost equaled doxorubicin, while the value of the other extracts was lower (Table 3).

The three extracts have a positive correlation between percentage of apoptosis and caspase-3. Although dichloromethane showed lower percentage of apoptosis and caspase-3, but they still have strong cytotoxicity $(99.85 \mu \mathrm{g} / \mathrm{mL})$, which shows potency as natural anticancer agents.

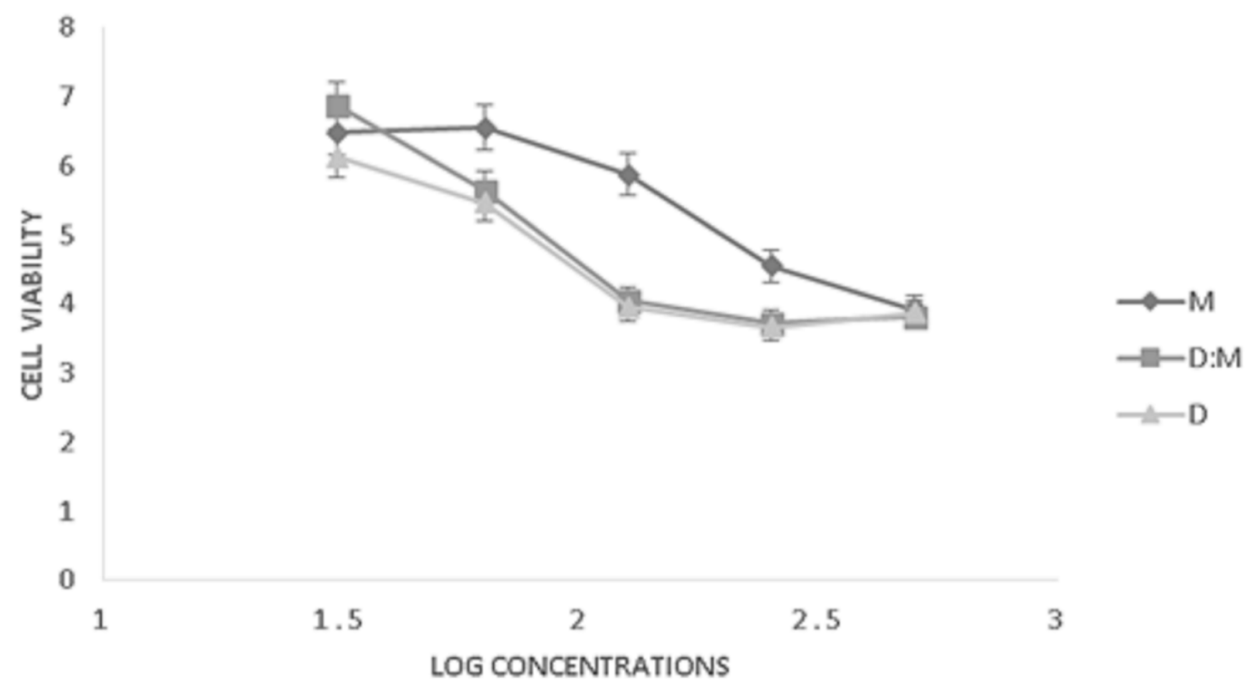

Figure 1. Breast cancer T47D cell viability after treatment with extracts of Ancorina sp. Methanol (M), Dichloromethane:Methanol (D:M) and Dichloromethane (D). 
Table 1. IC $_{50}$ values of Ancorina sp. extracts.

\begin{tabular}{|l|l|}
\hline Treatments & IC $_{50}$ value $(\boldsymbol{\mu g} / \mathbf{m L})$ \\
\hline Methanol & $84.25^{\mathrm{a}} \pm 9.52$ \\
\hline Dichloromethane:methanol $(1: 1)$ & $121.45^{\mathrm{b}} \pm 10.11$ \\
\hline Dichloromethane & $99.85^{\mathrm{ab}} \pm 11.79$ \\
\hline
\end{tabular}

Note: different letter showed the significant difference at the 0.05 level
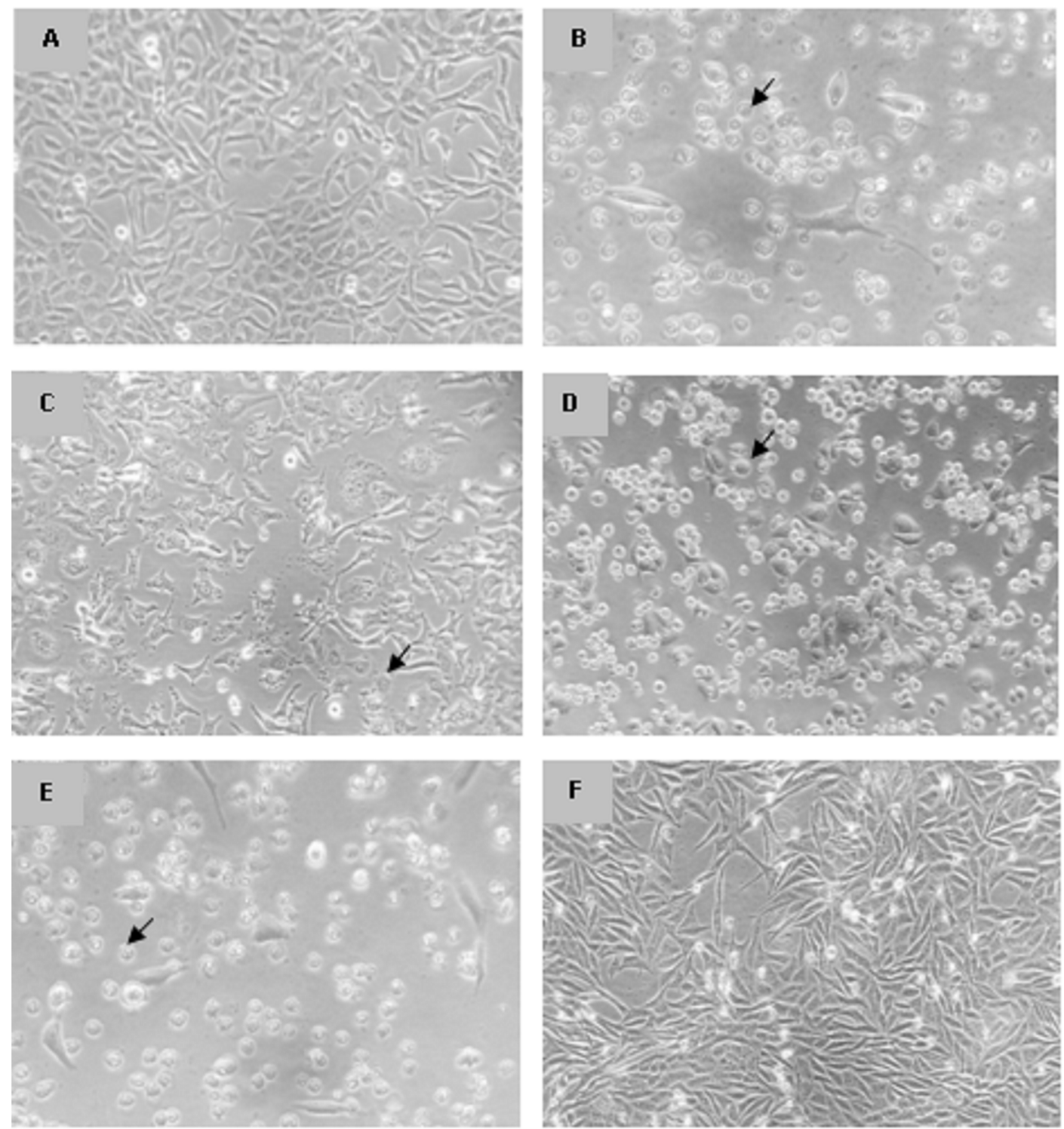

Figure 2. Cell morphology of breast cancer T47D cells after treatment with extracts of Ancorina sp. Control (A), Methanol (B), Dichloromethane:Methanol (C), Dichloromethane (D), Doxorubicin $(\mathbf{E})$ and DMSO (F). Arrow shows dead cells. 

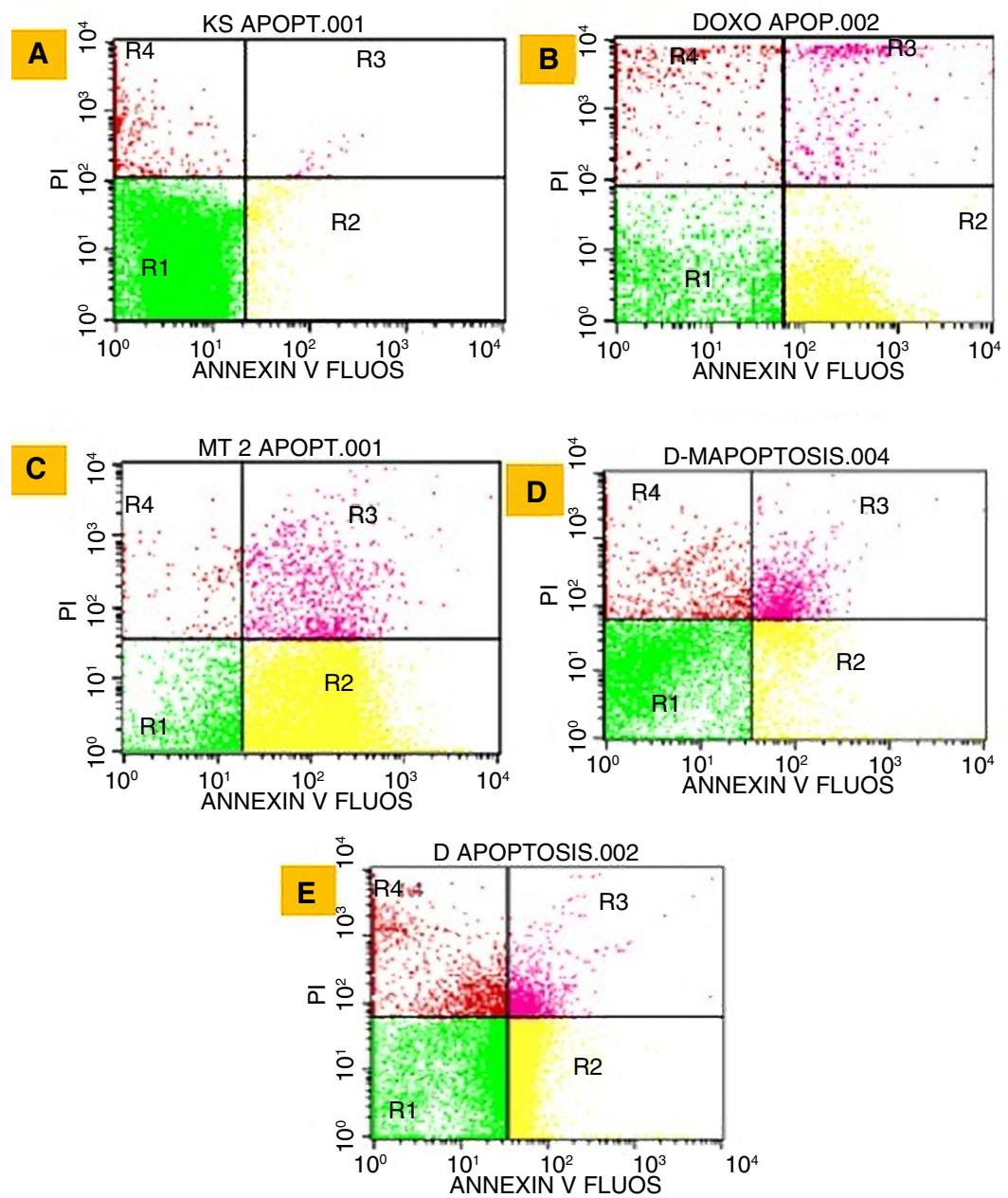

Figure 3. Detection of apoptosis markers of T47D cell. Cell control (A), doxorubicin (B), methanol (C), dichloromethane:methanol (1:1) (D), and dichloromethane (E). R1 (normal cells), R2 (early apoptosis cells), R3 (late apoptotic cells), and R4 (necrosis cells).

Table 2. Percentage of T47D cell population after treatment of crude extracts of Ancorina sp.

\begin{tabular}{|c|c|c|c|c|}
\hline \multirow[b]{2}{*}{ Treatment } & \multirow{2}{*}{$\begin{array}{c}\text { Applied } \\
\text { concentration } \\
\text { (IC } \text { Value }_{50} \text { value }\end{array}$} & \multicolumn{3}{|c|}{ Percentage of cell (\%) } \\
\hline & & Normal & $\begin{array}{c}\text { Early + Late } \\
\text { apoptosis }\end{array}$ & Necrosis \\
\hline Methanol & 84.25 & $6.94 \pm 0.21$ & $88.68^{a} \pm 0.47$ & $4.38 \pm 0.25$ \\
\hline $\begin{array}{l}\text { Dichlorometane } \\
\text { Methanol }(1: 1)\end{array}$ & 121.45 & $65.51 \pm 2.79$ & $27.54^{b} \pm 0.93$ & $7.37 \pm 1.65$ \\
\hline Dichlorometane & 99.85 & $39.29 \pm 1.60$ & $53.63^{c} \pm 1.42$ & $7.60 \pm 0.91$ \\
\hline Doxorubicin & 5 & $20.65 \pm 2.09$ & $75.74^{d} \pm 1.58$ & $3.67 \pm 0.44$ \\
\hline Negative control & - & $92.93 \pm 0.01$ & $1.84^{e} \pm 0.15$ & $5.34 \pm 0.21$ \\
\hline
\end{tabular}

Note: different letter showed the significant difference at the 0.05 level. Statistical analysis is focused to percentage of apoptosis among group. 

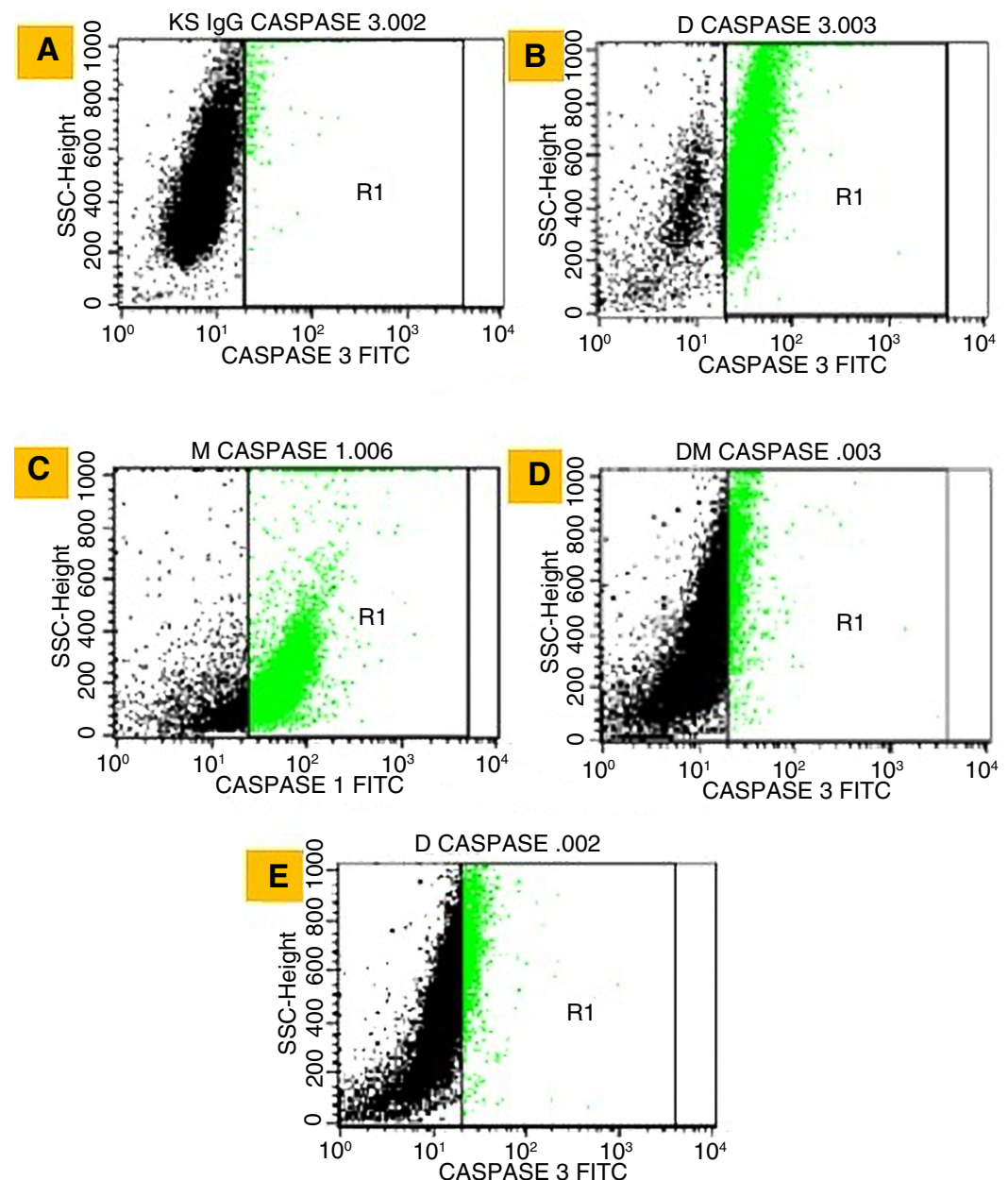

Figure 4. Detection of caspase-3 activation in breast cancer T47D cells after treatment with extracts of Ancorina sp. Negative control (A), Doxorubicin (B), Methanol (C), Dichloromethane:Methanol (D) and Dichloromethane (E).

Table 3. Percentage of caspase-3 activation after treatment by crude extracts of Ancorina sp.

\begin{tabular}{|l|c|c|}
\hline \multicolumn{1}{|c|}{ Treatments } & $\begin{array}{c}\text { Applied consentrations } \\
\mathbf{I C}_{\mathbf{5 0}}(\mathbf{\mu} \mathbf{g} / \mathbf{m L})\end{array}$ & Caspase-3 (\%) \\
\hline Methanol & 84.25 & $77.87 \pm 5.81$ \\
\hline $\begin{array}{l}\text { Dichlorometane : } \\
\text { Methanol (1:1) }\end{array}$ & 121.45 & $12.66 \pm 3.30$ \\
\hline Dichlorometane & 99.85 & $12.97 \pm 2.11$ \\
\hline Doxorubicin & 5 & $91,53 \pm 4.09$ \\
\hline Negative control & - & $1.54 \pm 0.00$ \\
\hline
\end{tabular}




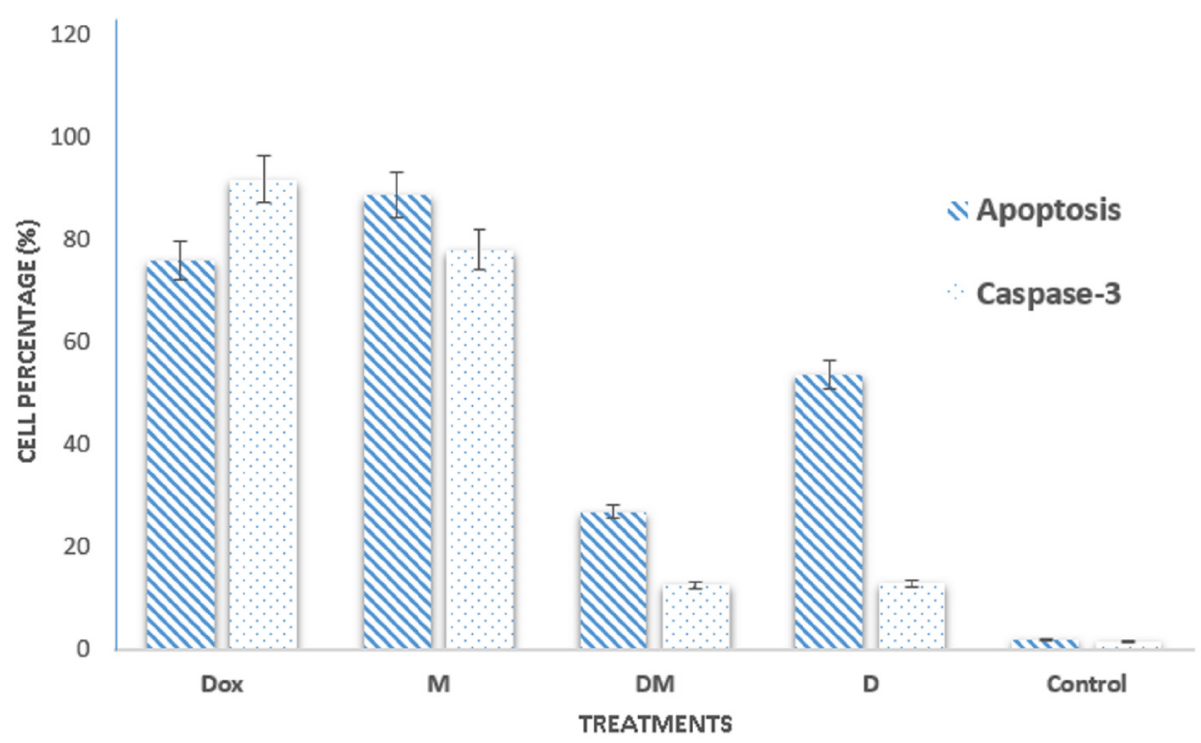

Figure 5. Correlation between percentage of apoptosis and caspase 3 activation in breast cancer T47D cells after treatment with extracts of Ancorina sp. Doxorubicin (Dox), Methanol (M), Dichloromethane:Methanol (1:1) (D:M), Dichloromethane (D), and negative control (control).

\section{Discussion}

Sponges are highly diverse in Indonesia. In particular, encrusting sponges abundantly live in Gunung Kidul, Yogyakarta. Marine sponges produce some secondary metabolites, which can be used as antiviral ${ }^{22}$, antimicrobial ${ }^{22,23}$, antifungal ${ }^{22}$, and anticancer drugs $^{17,24,29}$. The cell adhesion and immune system in sponge allow the different forms of the body $\operatorname{plan}^{30}$. When encrusting sponges grow together, sponges can survive by producing chemicals to kill fast dividing cells from the neighboring sponges. This ability of the chemicals can be used for chemotherapy since the basis of chemotherapy treatments is to disturb cancer cell growth $^{31}$.

Sponge Ancorina sp. is a member of family Ancorinidae, which contains bioactive compounds such as ancorinoside BD, penazetidine A (Penares sollasi), ecionines A \& B (Ecionemia sp.) and Iso malabaricane triterpenes (Rhabdastrella globostellata) ${ }^{32}$. Ancorinoside is a MT1-matrix metalloproteinase inhibitor in the development and metastasis of tumor cells ${ }^{33}$, whereas Penazetidine A strongly inhibits PKC- $\beta 1$ activity in tumor cells with $\mathrm{IC}_{50}$ value $0.3 \mu \mathrm{g} / \mathrm{mL}^{34}$.

Ecionines A (biemnadin) and B (meridine) are anticancer compounds for many cancer cells, including bladder cancer cells $^{33}$. Further, Iso malabaricane triterpenes were also found to be anticancer after testing on three types of cancer cells, namely L5178Y (mouse lymphoma), HeLa (human cervical carcinoma), and PC-12 (pheochromocytoma in mice ${ }^{35}$. Ancorina sp. is a source of bioactive compounds such as ancorinoside $\mathrm{A} \mathrm{Mg}$ salt, ancorinolates $\mathrm{AC}$, bis-ancorinolate $\mathrm{B}$, ancorinazole, indolo [3,2-a] carbazole, and (+) - 7-bromotrypargine ${ }^{36-38}$. These previous data show the high potency of Ancorinidae to be used as natural anticancer agents; hence this study is focused on the potency of Ancorina sp. as an anticancer agent and its mechanism, which is possibly through apoptosis induction.
Cytotoxicity is categorized into three levels by $\mathrm{IC}_{50}$ extract values. Very strong cytotoxicity has $\mathrm{IC}_{50}$ less than $10 \mu \mathrm{g} / \mathrm{mL}$, strong cytotoxicity has $\mathrm{IC}_{50}$ values between $10-100 \mu \mathrm{g} / \mathrm{mL}$, and moderate cytotoxicity has $\mathrm{IC}_{50}$ values between $100-500 \mu \mathrm{g} / \mathrm{mL}^{39}$. According to these ranges, $\mathrm{IC}_{50}$ of the methanol and dichloromethane extracts in the present study had strong cytotoxic ability, while dichloromethane:methanol (1:1) extract belonged to moderate cytotoxicity. Ancorina sp. extracts have greater value of $\mathrm{IC}_{50}$ compared with the study $^{34}$, which mentioned penazetidine A, a bioactive compound of marine sponge and highly inhibits PKC- $\beta 1$ activity in tumor cells with lower $\mathrm{IC}_{50}$ of $0.3 \mu \mathrm{g} / \mathrm{mL}$. This difference is due to the non-fractionated extract of our sponge, so that unsorted bioactive compounds possibly affect the cytotoxicity ability of extracts ${ }^{34}$.

Bioactive compounds from natural products depend on solvents. Based on the polarity of solvents, in the present study, Ancorina sp. extracts with polar solvent (methanol) lead to a higher apoptosis than non-polar (dichloromethane) or combination. These results are supported by a previous study that showed some compounds of Ancorinidae, such as ancorinoside BD, penazetidine $\mathrm{A}$, echionines $\mathrm{A}$ and $\mathrm{B}$ and isomalabaricane triterpenes, are polar compounds that have anti-tumor and anti-cancer characteristics $^{32}$. Interestingly, some studies in sponge also show same phenomenon such as cytotoxic compounds from sponge Dactylospongia elegans and Pachychalina alcaloidifera has been isolated using polar solvent methanol ${ }^{14,15}$. Terpenoids from sponge Iricina sp. and Spongia sp. have been isolated using polar solvent ethanol ${ }^{14,15,17}$. Bioactive compounds of sponge, both antiviral, antimicrobial, antifungal, and anticancer compounds have been successfully isolated by polar solvent as methanol ${ }^{19-21}$ and ethanol $^{22}$. Considering all extracts in this study have low necrosis values (Table 2), they are safe to be used as medicine. Therefore, further studies are needed to find out the specific compounds of Ancorina sp. extracts. 
Apoptosis can be triggered by extrinsic stimulation through death receptors on cell surfaces, such as TNF $\alpha$ (Tumor Necrosis Factor- $\alpha$ ), Fas receptor (CD95 / APO1) and TRAIL (TNF related to ligand-inducing apoptosis) or by intrinsic stimulation through mitochondrial signaling pathways. In these two main pathways, activation of cysteine aspartyl proteases or caspase can produce mitochondrial permeabilization membrane, chromatin condensation and DNA fragmentation. These events stimulate the cells that are undergo apoptosis and lead to a distinctive cell morphology, such as the appearance of pyknosis, chromatin condensation, nucleus fragmentation, and apoptotic body formation, but organelles are still intact ${ }^{40}$. This can be seen in the present study in Figure 2.

Apoptotic pathways commonly occur by the activation of caspase-3, which is the effector of intrinsic, extrinsic and perforin pathways $^{41}$. Caspase- 3 is a key protease that is activated during the early stages of apoptosis. Caspase- 3 is proteolytically active, cuts and activates other caspases, as well as relevant targets such as targets in the cytoplasm (D4-GDI and Bcl-23) and nucleus (poly (ADP-ribose) polymerase; PARP1) ${ }^{42}$.

In the present study, the highest percentage of caspase-3 was detected in methanol extract, which almost equal to doxorubicin, while the other extracts was lower (Table 3). Doxorubicin as a commercial drug in chemotherapy revealed a high percentage of apoptotic cells and caspase-3 activation. Among Ancorina sp. treatment groups, methanolic extract showed the highest percentage of both apoptosis and caspase-3. Interestingly, the methanolic extract showed a higher percentage than doxorubicin, and revealed its great potency to be used as a cancer medicine (Table 3).

The three extracts in this study have a positive trend between percentage of apoptosis and caspase-3 activation. Although dichloromethane showed a lower percentage of apoptosis and caspase-3, they had strong cytotoxicity $(99.85 \mu \mathrm{g} / \mathrm{mL})$ which shows potential as natural anticancer agents. It is possible that anticancer mechanism of dichloromethane and mixture of dichloromethane and methanol (1:1) excludes caspase-3 activation as effector caspases. Another pathway, such as caspase-6 or 7 , can also induce apoptosis in T47D breast cancer cells ${ }^{27}$. More investigation is needed to elucidate the anticancer mechanism of these extracts.

\section{Conclusions}

All extracts of Ancorina sp. have strong or moderate cytotoxicity and have the ability to induce apoptosis in T47D human breast cancer cell line.

\section{Data availability}

Underlying data

Open Science Framework: Apoptosis induction on human breast cancer T47D cell line by extracts of Ancorina sp., https://doi. org/10.17605/OSF.IO/AEJ96 ${ }^{43}$

Data are available under the terms of the Creative Commons Zero "No rights reserved" data waiver (CC0 1.0 Public domain dedication).

\section{Grant information}

This work was financially supported by Penelitian Dasar Unggulan Perguruan Tinggi No: 24/UN1/DITLIT/DIT-LIT/ LT/2018 from Indonesia Ministry of Research, Technology and Higher education (to W.A.S.T).

The funders had no role in study design, data collection and analysis, decision to publish, or preparation of the manuscript.

\section{Acknowledgements}

We acknowledge Nur Faizah, Rudi Nirwantoro, and Ratih Aryasari for the fruitful discussions and helping in sponge sampling and identification.
1. IARC: International Agency for Research on Cancer (IARC) Official Website. [Online]. 2018; [Accessed 20 Apr. 2018].

Reference Source

2. Kawabe $\mathrm{T}: \mathrm{G}_{2}$ checkpoint abrogators as anticancer drugs. Mol Cancer Ther. 2004; 3(4): 513-519.

PubMed Abstract

3. Maione $\mathrm{P}$, Rossi A, Airoma G, et al:: The role of targeted therapy in non-small cell lung cancer. Crit Rev Oncol Hematol. 2004; 51(1): 29-44. PubMed Abstract | Publisher Full Text

4. Vasudev NS, Reynolds AR: Anti-angiogenic therapy for cancer: current progress, unresolved questions and future directions. Angiogenesis. 2014; 17(3): 471-94

PubMed Abstract | Publisher Full Text | Free Full Text

5. Dickson MA, Schwartz GK: Development of cell-cycle inhibitors for cancer therapy. Curr Oncol. 2009; 16(2): 36-43.

PubMed Abstract | Publisher Full Text | Free Full Text

6. Płonka J, Latocha M: [Photodynamic therapy in the treatment of breast cancer] Pol Merkur Lekarski. 2012; 33(195): 173-5.

PubMed Abstract
7. Gerl R, Vaux DL: Apoptosis in the development and treatment of cancer. Carcinogenesis. 2005; 26(2): 263-270. PubMed Abstract | Publisher Full Text

8. Mohammad RM, Muqbil I, Lowe L, et al.: Broad targeting of resistance to apoptosis in cancer. Semin Cancer Biol. 2015; 35(Suppl): S78-S103. PubMed Abstract | Publisher Full Text | Free Full Text

9. Rossi D, Gaidano G: Messengers of cell death: apoptotic signaling in health and disease. Haematologica. 2003; 88(2): 212-218. PubMed Abstract

10. Würstle ML, Laussmann MA, Rehm $M$ : The central role of initiator caspase-9 in apoptosis signal transduction and the regulation of its activation and activity on the apoptosome. Exp Cell Res. 2012; 318(11): 1213-1220. PubMed Abstract | Publisher Full Text

11. Essack M, Bajic VB, Archer JA: Recently confirmed apoptosis-inducing lead compounds isolated from marine sponge of potential relevance in cancer treatment. Mar Drugs. 2011; 9(9): 1580-1606. PubMed Abstract | Publisher Full Text | Free Full Text

12. Rady HM, Hassan AZ, Salem SM, et al.: Induction of apoptosis and cell cycle arrest by Negombata magnifica sponge in hepatocellular carcinoma. 
Med Chem Res. 2016; 25(3): 456-465. Publisher Full Text

13. Bae W, Lim HK, Kim KM, et al:: Apoptosis-Inducing Activity of Marine Sponge Haliclona sp. Extracts Collected from Kosrae in Non small Cell Lung Cancer A549 Cells. Evid Based Complement Alternat Med. 2015; 2015: 717959. PubMed Abstract | Publisher Full Text | Free Full Text

14. Ebada SS, De Voogd N, Kalscheuer R, et al:: Cytotoxic drimane meroterpenoids from the Indonesian marine sponge Dactylospongia elegans. Phytochem Lett. 2017; 22: 154-158

Publisher Full Tex

15. Cavalcanti BC, Sombra CM, de Oliveira JH, et al: Cytotoxicity and genotoxicity of ingenamine $\mathrm{G}$ isolated from the Brazilian marine sponge Pachychalina alcaloidifera. Comp Biochem Physiol C Toxicol Pharmacol. 2008; 147(4): 409-415. PubMed Abstract | Publisher Full Text

16. Carreira J, Paula D, Cristina V, et al.: Trypanocidal activity of organic extracts from the Brazilian and Spanish marine sponges. Rev Bras Farmacogn. 2015; 25(6): 651-656. Publisher Full Text

17. Abdjul DB, Yamazaki H, Kanno S, et al.: FuranoTerpenes, new types of protein tyrosine phosphatase 1B inhibitors, from two Indonesian marine sponges, Ircinia and Spongia spp. Bioorg Med Chem Lett. 2017; 27(5): 1159-1161. PubMed Abstract | Publisher Full Text

18. Beedesseea G, Ramanjoolooa A, Aubertc G, et al.: Cytotoxic activities of hexane, ethyl acetate and butanol extracts of marine sponges from Mauritian Waters on human cancer cell lines. Environ Toxicol Pharmacol. 2012; 34(2): 397-408. PubMed Abstract | Publisher Full Text

19. Willemsen PR: The Screening of Sponge Extracts for Antifouling Activity using a Bioassay with Laboratory-reared Cyprid Larvae of the Barnacle Balanus Amphitrite. Int Biodeter Biodegr. 1994; 34(3-4): 361-373 Publisher Full Text

20. Kumar MS, Pandita NS, Pal AK: LC-MS/MS as a tool for identification of bioactive compounds in marine sponge Spongosorites halichondriodes (Dendy 1905). Toxicon. 2012; 60(6): 1135-1147. PubMed Abstract | Publisher Full Text

21. Shaala LA, Youssef DTA, Badr JM, et al:: Bioactive alkaloids from the Red Sea marine Verongid sponge Pseudoceratina arabica. Tetrahedron. 2015; 71(41): 7837-7841.

Publisher Full Text

22. Yu HB, Gu BB, Wang SP, et al.: New diterpenoids from the marine sponge Dactylospongia elegans. Tetrahedron. 2017; 73(47): 6657-6661. Publisher Full Text

23. Skariyachan S, G Rao A, Patil MR, et al:: Antimicrobial potential of metabolites extracted from bacterial symbionts associated with marine sponges in coastal area of Gulf of Mannar Biosphere, India. Lett Appl Microbiol. 2014; 58(3): 231-41. PubMed Abstract | Publisher Full Text

24. Bedesee G, Ramanjooloo A, Aubert G, et al.: Ethyl acetate extract of the Mauritian sponge Jaspis sp. induces cell arrest in human promyelocytic leukemia cells. Environ Toxicol Pharmacol. 2013; 36(1): 58-65. PubMed Abstract | Publisher Full Text

25. Mahdian D, Iranshahy M, Shakeri A, et al.: Cytotoxicity evaluation of extracts and fractions of five marine sponges from the Persian Gulf and HPLC fingerprint analysis of cytotoxic extracts. Asian Pac J Trop Biomed. 2015; 5(11): 896-901. Publisher Full Text

26. Beesoo R, Bhagooli R, Neergheen-Bhujun VS, et al.: Antibacterial and antibiotic potentiating activities of tropical marine sponge extracts. Comp Biochem Physiol C Toxicol Pharmacol. 2017; 196: 81-90. PubMed Abstract | Publisher Full Text

27. Mooney M, Al-sakkaf KA, Brown BL, et al.: Apoptotic mechanisms in T47D and
MCF-7 human breast cancer cells. Br J Cancer. 2002; 87(8): 909-917. PubMed Abstract | Publisher Full Text | Free Full Text

28. Ji Y, Yu M, Qi Z, et al:: Study on apoptosis effect of human breast cancer cell MCF-7 induced by lycorine hydrochloride via death receptor pathway. Saudi Pharm J. 2017; 25(4): 633-637. PubMed Abstract | Publisher Full Text | Free Full Text

29. Su JH, Chang W, Chen $\mathrm{H}$, et al: : 10-acetylirciformonin B, a sponge furanoterpenoid, induces DNA damage and apoptosis in leukemia cells. Molecules. 2012; 17(10): 11839-48.

PubMed Abstract | Publisher Full Text | Free Full Text

30. Wiens M, Krasko A, Perovic S, et al:: Caspase-mediated apoptosis in sponges: Cloning and function of the phylogenetic oldest apoptotic proteases from Metazoa. Biochim Biophys Acta. 2003; 1593(2-3): 179-189. PubMed Abstract | Publisher Full Text

31. Kustrin SA, Morton D, Kettle C: Structural Characteristic of Bioactive Marine Natural Products. In: Kim SK, ed. Marine Biomaterials: Characterization, Isolation and Applications. CRC Press Taylor \& Francis Group. 2013; 177. Reference Source

32. Fujita M, Nakao Y, Matsunaga S, et al.: Ancorinosides B-D, inhibitors of membrane type 1 matrix metalloproteinase (MT1-MMP), from the marine Sponge Penares sollasi Thiele. Tetrahedron. 2001; 57(7): 1229-1234. Publisher Full Text

33. Barnes EC, Said NABM, Williams ED, et al.: Ecionines A and B, two new cytotoxic pyridoacridine alkaloids from the Australian marine sponge, Ecionemia geodides. Tetrahedron. 2010; 66: 283-287. Publisher Full Text

34. Nagle DG, Zhou Y, Mora FD, et al:: Mechanism targeted discovery of antitumor marine natural products. Curr Med Chem. 2004; 11(13): 1725-56. PubMed Abstract | Publisher Full Text | Free Full Text

35. Fouad MA, Debbab A, Wray V, et al:: New bioactive alkaloids from the marine sponge Stylissa sp. Tetrahedron. 2012; 68: 10176-10. Publisher Full Text

36. Ohta E, Ohta S, Ikegami S: Ancorinoside A Mg salt from the marine sponge, Ancorina sp., which specifically inhibits blastulation of starfish embryos. Tetrahedron. 2001; 57(22): 4699-4703. Publisher Full Text

37. Meragelman KM, West LM, Northcote PT, et al.: Unusual sulfamate indoles and a novel indolo[3,2-a]carbazole from Ancorina sp. J Org Chem. 2002; 67(19): $6671-7$.

PubMed Abstract | Publisher Full Text

38. Davis RA, Duffy S, Avery VM, et al.: (+)-7-Bromotrypargine: an antimalarial $\beta$-carboline from the Australian marine sponge Ancorina sp. Tetrahedron Lett. 2010; 51: 583-585. Publisher Full Text

39. Weerapreeyakul NN, Barusrux $\mathrm{S}$, Thitimetharoch $\mathrm{T}$, et al.: Evaluation of the anticancer potential of six herbs against a hepatoma cell line. Chin Med. 2012; 7(1): 15 PubMed Abstract | Publisher Full Text | Free Full Text

40. Nikoletopoulou V, Markaki M, Palikaras K, et al:: Crosstalk between apoptosis, necrosis and autophagy. Biochim Biophys Acta. 2013; 1833(12): 3448-3459. PubMed Abstract | Publisher Full Text

41. Bali R, Chandra A, Verma R: Apoptosis in normal oral tissues and odontogenesis. Eur J Gen Dent. 2013; 2(3): 195-198. Publisher Full Text

42. Affar EB, Germain M, Winstall E, et al:: Caspase-3-mediated processing of poly(ADPribose) glycohydrolase during apoptosis. J Biol Chem. 2001; 276(4): 2935-42. PubMed Abstract | Publisher Full Text

43. Tunjung WAS: Apoptosis Induction on Human Breast Cancer T47D Cell Line by Extracts of Ancorina Sp. OSF. 2019. http://www.doi.org/10.17605/OSF.IO/AEJ96 


\section{Open Peer Review}

\section{Current Peer Review Status: ? ?}

\section{Version 1}

Reviewer Report 21 March 2019

https://doi.org/10.5256/f1000research.19228.r44188

(C) 2019 Daniels R. This is an open access peer review report distributed under the terms of the Creative Commons Attribution License, which permits unrestricted use, distribution, and reproduction in any medium, provided the original work is properly cited.

\section{Richard Luke Daniels \\ Department of Biology, The College of Idaho, Caldwell, ID, USA}

This paper describes the cytotoxic effects of extracts from a marine sponge. The authors provide evidence that extracts were cytotoxic, and that methanol-extracts were the most cytotoxic (as measured by MTT assay). Additional studies showed that the mechanism of cell death is likely through apoptosis (as measured by examining Annexin V/PI staining and caspase 3 activity via flow cytometry). These are novel results that contribute to the search for anti-cancer agents, and it is this reviewer's opinion that indexing is warranted. There are a few minor modifications that I would suggest making before finalizing this manuscript.

\section{Methods:}

It would be helpful to include additional details about the methods, such as:

1. specific extraction methods.

2. the method in which the IC50 was calculated.

\section{Figure 1:}

This reviewer agrees that the MTT data supports the idea that these various extracts are cytotoxic. In Figure 1, it seems that the $y$-axis is the percentage of cells that are healthy relative to controls (?), but the units are not given. It would be helpful in Figure 1 to:

1. give the units for the $y$-axis.

2. provide some explanation of the dose that is given in each treatment (currently given in the methods).

3. know the number of trials this experiment represents.

4. What is the $n$, what do the error bars represent? (Standard error? Standard deviation?)

It might also be beneficial to do an ANOVA to better understand whether differences among these experimental treatments might be statistically significant (in other words, are the dose-dependent changes in cell viabilities statistically different from each other?). I do not consider this to be essential for indexing. 


\section{Figure 2:}

This reviewer agrees that these treatment compounds seem to negatively impact cells (based on their morphology). It would be beneficial to:

1. describe the differences that were observed for each treatment condition, as there seems to be some variation ( $C$ vs. E for example).

\section{Figure 3 \& 4:}

It appears that the flow cytometry experiments were repeated a number of times, as implied by the variability that is reported in Tables $2 \& 3$ (+/- values). It would be helpful to:

1. give the number of times the experiment repeated.

2. state what this variability represents (standard error? Standard deviation?).

Is the work clearly and accurately presented and does it cite the current literature? Partly

Is the study design appropriate and is the work technically sound?

Yes

Are sufficient details of methods and analysis provided to allow replication by others? Partly

If applicable, is the statistical analysis and its interpretation appropriate? Partly

Are all the source data underlying the results available to ensure full reproducibility? Partly

Are the conclusions drawn adequately supported by the results?

Yes

Competing Interests: No competing interests were disclosed.

Reviewer Expertise: Cell physiology, Cell signaling

I confirm that I have read this submission and believe that I have an appropriate level of expertise to confirm that it is of an acceptable scientific standard, however I have significant reservations, as outlined above.

Reviewer Report 26 February 2019

https://doi.org/10.5256/f1000research.19228.r44186

(C) 2019 Sumitro S. This is an open access peer review report distributed under the terms of the Creative Commons Attribution License, which permits unrestricted use, distribution, and reproduction in any medium, provided the original work is properly cited. 


\section{Sutiman Bambang Sumitro}

Department of Biology, Faculty of Sciences, Brawijaya University, Malang, Indonesia

\section{Page 3:}

\section{Methods: Extraction:}

Statement:

"Fresh samples were crushed in a blender in methanol, dichloromethane and dichloromethane methanol (1:1) then macerated for 24 hours. The samples were filtered and the residue then was re-extracted for two times. The total filtrate was then evaporated to obtain crude extract paste."

\section{Questions:}

1. What is used to filter the extract?

2. What is used to evaporate? What degree of temperature is used to evaporate?

3. What is the type of the tool?

\section{Statement:}

"The cells were cultured in RPMI 1640 medium supplemented with 10\% FBS, 2\% penicillin streptomycin and $0.5 \%$ Fungi zone. Cells were harvested after reaching $80 \%$ confluence using $0.25 \%$ Trypsin-EDTA. Cells were cultured in 96-well micro plates $(1 \times 103$ cells/well) in $100 \mu \mathrm{L}$ RPMI and incubated at $37^{\circ} \mathrm{C}$ with $5 \% \mathrm{CO} 2$ overnight".

Suggestion:

It's better to explain what DMSO, MTT, etc., stand for.

\section{Page 4:}

\section{Results:}

Figure 1. Breast cancer T47D cell viability after treatment with extracts of Ancorina sp. Methanol (M), Dichloromethane: Methanol (D:M) and Dichloromethane (D).

Questions:

1. What is the unit of the cell viability?

2. The log concentration (?).

3. Add the scaling line next to the numbers.

\section{Page 5:}

Table 1. IC50 values of Ancorina sp. extracts. Treatments IC50 value $(\mu \mathrm{g} / \mathrm{mL})$

Methanol

Dichloromethane:methanol (1:1)

Dichloromethane
$84.25 a \pm 9.52$

$121.45 b \pm 10.11$

$99.85 a b \pm 11.79$ 
Note: different letters showed the significant difference at the 0.05 levels.

Questions:

1. How is the $\mathrm{IC}_{50}$ calculated?

2. Why do dichloromethane (non-polar solvent) and methanol indicate moderate cytotoxicity, while on the other hand, methanol solvent (polar solvent) indicates the highest cytotoxicity?

Figure 2. Cell morphology of breast cancer T47D cells after treatment with extracts of Ancorina sp. Control (A), Methanol (B), Dichloromethane:Methanol (C), Dichloromethane (D), Doxorubicin (E) and DMSO (F). Arrow shows dead cells.

Questions:

1. What are the morphological differences among the treatments? This needs to be explained. Is it only to show dead and living cells? If this is the case one figure is enough.

2. The figures were taken using what kind of microscope?

3. Add the microscopic scale on the figure.

\section{Page 7:}

Figure 4. Detection of caspase-3 activation in breast cancer T47D cells after treatment with extracts of Ancorina sp. Negative control (A), Doxorubicin (B), Methanol (C), Dichloromethane: Methanol (D) and Dichloromethane.

Question: What is R1?

\section{Page 8:}

Figure 5. Correlation between percentage of apoptosis and caspase 3 activation in breast cancer T47D cells after treatment with extracts of Ancorina sp. Doxorubicin (Dox), Methanol (M), Dichloromethane: Methanol (1:1) (D:M), Dichloromethane (D), and negative control (control).

Suggestion: The figure is not clear. Add the scaling line next to the numbers.

\section{Page 8:}

Ancorina sp. is a source of bioactive compounds such as ancorinoside A Mg salt, ancorinolates AC, bis-ancorinolate B, ancorinazole, indolo [3,2-a] carbazole, and (+) - 7bromotryparg.

Suggestion: Mention the characteristics of these compounds e.g. the level of their polarity.

Is the work clearly and accurately presented and does it cite the current literature? 
Yes

Is the study design appropriate and is the work technically sound?

Yes

Are sufficient details of methods and analysis provided to allow replication by others? Partly

If applicable, is the statistical analysis and its interpretation appropriate?

I cannot comment. A qualified statistician is required.

Are all the source data underlying the results available to ensure full reproducibility? No source data required

Are the conclusions drawn adequately supported by the results?

Yes

Competing Interests: No competing interests were disclosed.

Reviewer Expertise: Herbal medicine, complexity and Nano Biological approaches

I confirm that I have read this submission and believe that I have an appropriate level of expertise to confirm that it is of an acceptable scientific standard, however I have significant reservations, as outlined above.

The benefits of publishing with F1000Research:

- Your article is published within days, with no editorial bias

- You can publish traditional articles, null/negative results, case reports, data notes and more

- The peer review process is transparent and collaborative

- Your article is indexed in PubMed after passing peer review

- Dedicated customer support at every stage

For pre-submission enquiries, contact research@f1000.com 